\section{ANIMAL TOOL-USERS, ENGINEERS, AND MECHANICS}

Those who maintain that the lower animals, the sub human families, in all manifestations of intelligence, are governed and directed solely and wholly by in stinct, a ssert that such creatures never make use of tools. Yet, of these observers, even the most careless and most casual have, doubtless, time and again witnessed the use of tools by animals, though they may have failed to recognize it as such.

The spider which seeks out a pebble and anchors he web with it in order to hold it taut, or to keep it from being blown away by the wind, clearly makes use of a tool; the pebble in this instance is as much a tool as an iron anchor fashioned by the hand of man would be to human beings under analogous eircumstances.

Prof. E. H. Webber, the famous anatomist and phy siologist, writes as follows:

"A spider had stretched its web between two post standing opposite each other, and had fastened it to a plint below for a third point. But as the attachmen below was of ten broken by the garden work, by passers-by, and in other ways, the little animal extricate itself from the difficulty by spinning its web round a little stone, and fastened this to the lower part of it web, swinging freely, and so to draw the web down by ts weight instead of

Not long ago I saw a spider use a broken nail as a anchorforher web. She had spun hertrapin a square window in a partition wall. This partition stood between the saw room and the kiln or dry room of a planing mill, and the timber that was to be dried out was passed through the window from the saw room to the dry room. Of course. the lower stay rope of her web was frequently broken by the rafters, planks, etc., that was thrust through the window. The intelligent little across the window without making use of a lower sta rope; she found a small fragment of a broken nail, rope; she found a small fragment of a broken nail, in the elaboration of which she evinced high engineering skill, she finally drew the broken nail up to the bottom or lower margin of her wheel-shaped web, an there lashed it securely. The weight of the little piece of iron was sufficient to hold the web taut and to keep it stretched across the window.

Several years ago I saw a water moccasin make use of a novel method to secure its diner. I was fishing in Ouachita River, Arkansas. One day, when I saw
large moceasin busily engaged in the pursuit of minlarge moceasin busily engaged in the pursuit of min-
nows, the current was so swift and strong, however nows, the current was so swift and strong, however
that the snake missed its aim whenever it darted ou after one of these agile little fishes. Time and again it essayed to seize a minnow, only to be swept aside by the rapidly flowing water. Finally, it took a half tur of its tail about a bowlder, which rested on the botto of the stream, and, when a minnow came within reach, it suddenly darted out its head and neck and caugh the unwary little "silver sides." Here, so it seems to a ject.

Several years ago I was greatly worried by black ants, which had discovered some specimens (bird skins) on a table, and which they had attacked and were re moving piecemeal. I made four circles of tar on as many squares of brown paper and placed one of these squares beneath each leg of the table, so that the legs were encircled by the tar. This seemed to stop the ravages of the little thieves for several days, but eventually I again found them on the skins busily engaged in removing bits of flesh. On examination, $I$ discovered that they had brought in grains of sand from the street and had constructed a bridge or dike across the tar and had constructed a bridge or dike across the tar with these miniature blocks of stone. So very wonder-
ful was this intelligent act that I called in my friend, Dr. R. O. Cowling, proiessor of surgery in the University of Louisville, to witness it. I removed the circle which had been bridged by the ants and substituted a
fresh square. We then saw the ants bring sand grains rom the street and construct another bridge.

Reaumer, in his L'Histoire des Insectes, says that Cardinal Fleury told him that he saw ants on one occasion build a bridge of earth across some bird lime which had been spread on a tree; on another occasion the Cardinal saw these intelligent little architects build a floating bridge across a vessel of water surrounding the bottom of an orange tree tub. They used wood in the construction of this bridge, thus showing that they were aware of the nature of the material necessary to make their bridge a success ; also, that they possessed no small engineering skill. Still more wonderful is the account of Dr. Ellendorf, who writes that the ants which he observed bridged a saucer of water with a straw. He had placed the legs of a cupboard in saucers straw. He had placed the legs of a cupboard in saucers
of water, thus, for a few days, preventing the ravages of water, thus, for a few days, preventing the ravages
of the ants. Finally, however, they again gained access to the cupboard and were as bad as ever. On examination, he found a straw in one of the saucers which lay obliquely across the edge of the vessel and touched the leg of the cupboard; the ants were using the straw
for a bridge. "I now pushed the straw about an inch away from the cupboard leg," writes Dr. Ellendorf, "and immediately a terrible confusion arose. In a with hundreds of ants, feeling for the bridge in every direction with their antenne, running back again and coming in ever larger swarms, as though they had communicated to their comrades within the cupboard the fearful misfortune that had taken place. Mean while fearful misfortune that had taken place. Mean while
the newcomers continued to run along the straw, and not finding the leg of the cupboard, the greatest perplexity arose. They hurried round the edge of the saucer, and soon found out where the fault lay. Wilh united forces they quickly pulled and pushed at the straw, untilit again came into contact with the leg restored."

In this instance the ants were quick to seize on material ready to hand; they found in the straw a ready made and most efficacious bridge. They clearly showed that they recognized it as such, by replacing it when the doctor moved it away from the cupboard leg.

Many of the lower animals evince great architectural and engineering skill in the construction of their domi-

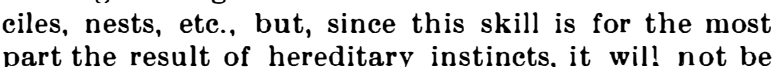
discussed in this paper. It so happens, however, that every now and then, sub-human ereatures show by their actions that their engineering feats are the result of reason; that they are elaborated and inaugurated to meet the exigencies of immediate and utterly un expected circumstances. Thus, on one occasion, where owing to excessive heat, one of the combs of a hive became detached and was in great danger of falling, the bees at once set to work and built a shoring pillar be tween the endangered comb and the one next to it. This pillar kept the comb from falling. The intelligent little engineers then rebuilt the attachments of the comb with wax, thus firmly fixing it to the walls of the shoring pillar and used the wax elsewhere. Each step in this engineering feat was witnessed by myself and I was forced to acknowledge that man himself could not have met the accident more intelligently and warded off evil consequences more effectually.

Bees are firm believers in the adage "Cleanliness is
next to godliness," consequently keep their hives spotlessly clean. They immediately carry out all filth and deposit it without the hive. Sometimes it happen that intruders, such as large moths, beetles, etc., in their wanderings stray into the domicile of a community of these exclusive little confectioners. At once war is declared, and the stranger is stung to death. war is declared, and the stranger is stung to death. wonderful how strong they are and what heavy bodies they are able to move ); if the dead stranger is too
heavy for them, they will bury it beneath masses of heavy for them, they will bury it beneath masses of
propolis, a substance that they extract from the popla and certain other trees. I once placed a large Polyphemus moth in a hive. The bees soon discovered the intruder, and an alarm was sent out. There was some confusion at first, but soon the brave little insects could be seen hurrying from all sides, and converging toward the invaded portion of the hive. Suddenly, the moths was attacked by dozens of bees, and was the moths was attacked by dozens of bees, and was
soon stung to death. They tried to drag the dead in soon stung to death. They tried to drag the dead infor their strength, they buried it beneath masses of propolis.

Some of the higher animals, such as the monkey and the elephant, on occasions, make as intelligent use of tools as men would under similar or like circumstances. A Capuchin monkey, which I owned for several years with his teeth, but they proved to be too hard. He with his teeth, but they proved to be too hard. He
then seized a stone which happened to be lying nea on the pavement, and, holding the nut with one paw, he brought the stone down on it with the other, thu effectually laying bare the longed-for kernels.

An Ateles, the property of Mr. Paul Devinney, of St. Louis, not only cracks nuts with a hammer, but also uses a "picker" in extracting the kernels. I. have mired his skill and dexterity.

Some monkeys are fully aware of the properties of the lever and of the advantage of leverage. In 1882 saw a monkey at the Fair Grounds, in St. Louis, Mo which would pry apart the bars of his eage with stick. When I gave him my cane, he would examin it carefully, as if mentally testing its strength: he would then place it between the bars at just the righ spot, and swing back on it with all his might. When through and "go on a prowl." Reugger, the Germa biologist and naturalist, deseribes a monkey which would "employ a stick wherewith to pry up the lid of a chest, which was too heavy for the animal to raise a chest, which

In 1889 there was on exhibition in New York a ver large and intelligent hog-nose monkey. This animal
was confined by itself, though there was a door between its cage and the one next to it. This door could be easily opened by the monkey, but a spring governe it in such manner that it would close unless held open.
The hog-nose was a sociable individual, and was very fond of visiting its neighbors. It could not bear, however, having the door closed on it, thus shutting it out from its own particular domicile, so it evolved the ingenious trick of chocking the door with a pan when-
ever it went calling! It would open the door, then place the pan in such a position that it could not swing to!

One day I removed the pan, and the monkey's dismay and uneasiness was very plainly manifested until restored it.

Elephants very frequently make use of tools. Sir John Tennant, Romanes, Dampier, and others say that these creatures, when passing through the jungle, break branches from the trees and use them $\varepsilon ;$ fans. phant that was on exhibition at the St. Louis Fair Grounds, I noticed that she was greatly worried and annoyed by the attacks of a swarm of large flies. These insects had settled on her back where she could not reach them with her proboscis or with her tail. She seemed to study the situation for a few moments; then, reaching out her trunk, she seized a mop-broom, which stood in the corner of her stall, and deliberately brush. ed off the greedy little bloodsuckers with it.

Mr. G. E. Peal stafes in Nature that he once saw a young elephant deliberately fashion a surgical instrufence and break ofĩ one of the pickets; this picket it further fractured with its trunk and one of its fore feet until it obtained a sharp fragment some 10 or 12 feet until it obtained a sharp fragment some 10 or 12
inches in length. Then, leaning forward on one of its forelegs, it thrust this fragment, which it grasped with its trunk, into its "armpit" and vigorously moved it to and fro. As a result of this operation, a large elephant leech was dislodged, which dropped to the ground and was at once ground to mincemeat beneath the horny toes of the saga

Jessie, the elephant mentioned above, had some knowledge of pneumatics. One day I tossed a peanut which fell to the ground some 8 or 10 inches beyond the utmost reach of her trunk. She stretched out this organ to its fullest extent $t$ sward the peanut, then blew through it a sudden, quick, and powerful blast. The peanut was hurled against the wall, from whence it bounded and then rolled beneath the feet of the in telligent animal, which at once swallowed it. I tried this experiment several times, each time with a like result.

\section{TIME OF transatlantic Passage again}

The speed of the transatlantic steamship continues to advance hy steady increments and the time of the ocean passage is curtailed hour by hour. That most successful ship, the "Kaiser Wilhelm der Grosse," of
the North German Lloyd Company, has now, for the third time, surpassed the record formerly held by the "Lucania" for the highest average speed from New York to European ports. This mark stood for several years at 22.01 knots, and was first broken by the "Kaiser Wilhelm," which covered the course at an average speed of 22.3 knots, a performance which she subsequently eclipsed by achieving an average of 22.50 knots.

On her last trip the same vessel ran from Sandy Hook Lightship to Cherbourg in 5 days 20 hours and 55 minutes, the exact length of her course being 3,190
miles. To do this the "Kaiser Wilhelm" must have miles. To do this the "Kaiser Wilhelm" must have
maintained an arerage speed, day and night, of $22 \cdot 65$ knots, or 26 land miles per hour. The most able all-day run of this vessel was made in May, 1898 when during a westbound trip she covered 580 knots in one day at an average speed of 24.17 knots an hour. The best previous all-day run was that of the "LuThe best previous all-day run was that of the "Lu-
cania," which covered 560 knots at an average speed of $23 \cdot 33$ knots.

\section{BROOMS AS GERM BREEDERS.}

Bacteriologists devote themselves to the detection, isolation, and destruction of bacteria, and strange to say, they do not appear to have given much attention household use. For example, the common house broom is both the habitation and breeding place for whole colonies of bacteria, and cases of disease have been traced to this apparently inoffensive article. At Königsberg a course in bacteriology is given by a physician, in which he maintains that the strictest santary and hygienic conditions in things pertaining to the house should be inculeated, and in this country in the Boston Cooking School, and doubtless elsewhere, there are many lectures given on bacteriology. The re frigerator is one of the danger spots, for bacteriologist tell us that the minutest organisms may thrive even in melted ice, and putrefactive bacteria once gaining access to the household refrigerator will breed and contaminate butter, milk, meat. and other food kept therein. Cupboards and closets also afford an excelent breeding place for the ever-present microbe, and housekeepers will do well to look to such articles as refrigerators, brooms, dusters, etc. 